\title{
PART 6. \\ INTERNATIONAL SUPPORT OF CARPATHIAN UKRAINE BY THE ORGANIZATIONS OF UKRAINIAN EMIGRATION
}

In the late 1930s, about 55 million Ukrainians lived in different countries of the world. "Most of them live behind our Carpathians," "Nova Svoboda" reported, "in addition to Subcarpathia Ukrainians live on different lands, including: 41 million in Great Ukraine (UkrSSR), 8 1/2 million in Galicia (Poland), 650 thousand in Czechoslovakia, $21 / 2$ million - in Bukovina and Bessarabia (Romania), 1 million - in the USA, 300 thousand - in Canada",529. After 1925, the centers of Ukrainian emigration in Europe finally crystallized. "Prague took first place, followed by Warsaw, and Vienna lost its meaning. New centers are emerging: Berlin and Paris. Weaker clusters of Ukrainian emigration are in Romania, Bulgaria, Belgium, Switzerland, England, Italy, Turkey, Latvia, Finland. Ukrainian emigration to Poland and France takes the first position"530.

Since the 80's of the XIX century Galician and Transcarpathian peasants migrated overseas. "Ukrainians or persons of Ukrainian descent before the war (WWII - Aut.) were roughly divided in America between its various countries: the United States of America - 700-800 thousand, Canada - 300-400 thousand, Brazil 50-60 thousand, Argentina - 50 thousand, other US countries 10-20 thousand"531. The above statistical material shows that the Ukrainian diaspora in quantitative terms was a significant force, from which the future of Carpathian Ukraine also belonged. On this basis, it is not surprising that the government of A. Voloshyn, who was in a difficult position, appealed to Ukrainians in foreign countries for help. It should be noted that "a great amount of working emigrants

\footnotetext{
${ }^{529}$ Нова свобода. 1938. 28 серпня.

${ }^{530}$ Баран С. Українська еміграція між двома світовими війнами. Енцчиклопедія Українознавства, Загальна частина. Т.2. К., 1995. С. 572.

531 Кубійович В. Закарпаття. Енциклопедія Украйнознавства. Словникова частина. Т. 2. К., 1995. С. 715-727.
} 
and their leaders sincerely and honestly wished their fellow countrymen a happy, free development, liberation from centuries-old alien enslavement, in every possible way supported their struggle for autonomy and political independence. At the same time, among the emigrants there were those who, expressing minority interests, were involved in different political intrigues around Transcarpathia, pursued anti-popular activities and, by blocking themselves with reactionary forces in the "old world", led our region to the tragedy on the eve of World War II"532. These ideas, expressed by the modern researcher M. Boldyzhar, make it possible to state that political events of 1938-1939 in Carpathian Ukraine were evaluated by various organizations of the Ukrainian diaspora ambiguously.

On December 22, 1938 "Nova Svoboda" published an appeal by representatives of the Ukrainian diaspora, which proposed the creation of a "National Fund of Carpathian Ukraine". "It is necessary to take advantage of that great exaltation," the statement said, "which has engulfed the Ukrainian people around the world. Everyone wants to help us. It is our duty to organize this much needed action and to move it as quickly as possible. Khust has already been influenced by many different plans, and we add one more to them: "Let's establish a National Fund". Let us create it today and let us tell about it to the whole Ukrainian world. It is the duty of the whole nation to build Carpathian Ukraine. Let us not boast that there are many of us - let us boast of what we can do!"533.

There were close relationships between the Government of Carpathian Ukraine and the various political parties, associations and communities of 9 countries. ${ }^{534}$. In the USA Carpathian Ukraine was supported by the "Organization of Democratic Revival of Ukraine", "Young Ukrainian Nationalists", "Committee for Defense of Carpathian Ukraine", "Ukrainian Red Cross", "Foreign Delegation of Carpathian Ukraine", "United Ukrainian Organizations of America". In Canada - "Ukrainian National Association", "Ukrainian Riflemen Community", "Olha Basarab Association of Ukrainian Women of

\footnotetext{
532 Болдижар М. Закарпаття між двома світовими війнами. Ужгород, 1993. С. 74.

${ }^{533}$ Нова свобода. 1938. 22 грудня.

534 Стерчо П. Національне відродження Карпатської України. Організація Украӥнських Націоналістів. 1929-1954. Мюнхен, 1955. С. 188.
} 
Canada", "Young Ukrainian Nationalists". In Czechoslovakia "Committee for Defense of Carpathian Ukraine", "Central Union of Ukrainian Organizations of the Czechoslovak Republic". In Germany - "Ukrainian National Union". In France - "Ukrainian People's Union". In Argentina - "Organization of the Democratic Revival of Ukraine". In Brazil - "Ukrainian Plowmen Union". In the Far East - "Ukrainian National Colony" in Harbin. In establishing relations of Carpathian Ukraine with the political organizations of the Ukrainian diaspora, the foreign PUN, in particular the department headed by Ya. Baranovskyi, played a significant role.

The Ukrainian diaspora in the United States can be conditionally divided into two main groups - the pro-Ukrainian one, which advocated a federation of Transcarpathians with the Czechs and Slovaks, and subsequently supported the activity of A. Voloshyn's government in the direction of building a sovereign state, and the second one - the Moscophiles, which often took a pro-Hungarian position. It is not surprising, therefore, that various organizations of the Transcarpathian Diaspora in the United States have differently treated the policy pursued by the autonomous government of A. Voloshyn.

On October 22, 1938 "Nova Svoboda" published a message "Ukrainians from America are protesting" which stated: "Representatives of the Ukrainian organizations in the United States of North America protest before diplomatic representatives of the great states, participants of the Munich conference, against the attempts of Hungary to enlarge its territory with the territory of subcarpathian Ukrainians" ${ }^{", 535}$. On October 23, 1938 the American Ukrainian organizations issued a "Manifesto", in which they demanded: "1) a fully independent state of Carpathian Ukraine, to which Presov and Spis regions should be attached; 2) protest against neighbors' plans; 3) immediate release of Ukrainian political prisoners; 4) transfer of troops and gendarmerie to the Ukrainian leadership; 5) gathering of Ukrainian troops to Carpathian Ukraine for border protection" 536 . The governments of all the great states were introduced to the Manifesto. The active support of Carpathian

535 Нова свобода. 1938. 22 жовтня.

${ }^{536}$ Нова свобода. 1938. 23 жовтня. 
Ukraine has been repeatedly urged by the American priest O. Nevytskyi: "Do your duty for your people and your land, do not break into different parties and groups, but join to one single national camp, under one leadership",537.

"Organization of Democratic Renaissance of Ukraine" (hereinafter referred to as ODVU), which was operating in New York, has taken on a fundraiser for the Transcarpathian population. Representatives of the Carpatho-Ukrainian emigration in the United States organized the "Committee of Defense of Transcarpathia", which was later renamed into "Committee of Defense of Carpathian Ukraine" (hereinafter referred to as COCU), with the assistance of the OVDU. It began its activities in such composition: V. Ben' (chairman), M. Ben', O. Dankanych (deputy chairman), Y. Haboda, A. Kost' (secretaries), T. Palosh (financial secretary), P. Ikalovych (treasurer), I. Boryshkevych, Y. Boryshkevych, M. Dankanych (control commission). O. Nevytsky was elected honorary chairman of the $\mathrm{COCU}^{538}$. According to P. Stercho, "this Committee has set itself the goal to take the troubled Transcarpathian Ukrainians of America out of the captivity of the Magyar-Moscophiles and, by guiding them along the lines of popular interests, to unite their support for the cause of the liberation of Carpathian Ukraine" 539 .

COCU initiated a number of events in New York, Philadelphia, Detroit, Cleveland, Chicago, Rochester, New Ark, on which resolutions were adopted in defense of Transcarpathia. At a meeting held on October 9, 1938 in Philadelphia, a fundraiser for Carpathian Ukraine was initiated. The organizers managed to raise 152.50 $\mathrm{USD}^{540}$. COCU, together with the "United Ukrainian Organizations of America", strongly condemned the Vienna arbitration award. Regarding this event, L. Myshuha, who represented the second organization, stated that "the verdict issued in Vienna on November 2, 1938 by the Divisional Commission on the issues of

\footnotetext{
537 Химинець Ю. Тернистий шлях до України. Ужгород: МПП «Гражда», 1996. C. 24.

538 Стерчо П. Карпато-Українська держава: 3 історії визвольної боротьби карпатських українців у 1919-1939 роках. Торонто, 1965. С. 95.

539 Ibid. C. 95.

${ }^{540}$ Ibid. C. 71-72.
} 
borders of Transcarpathia violates the ethnographic principles that formed the basis of the international conference in Munich and which were to be applied against the population of Transcarpathia. The decision of the Divisional Commission is a great shame for Carpathian Ukraine and for the whole Ukrainian people. American Ukrainians do not recognize this decision and protest against it ${ }^{\text {"541 }}$.

Fundraising for Carpathian Ukraine continued. In its February issue of 1939, "Nova Svoboda" published an article "Ukrainians in America for Carpathian Ukraine", in which it noted that "Ukrainian emigration abroad, especially in America and Canada, is concerned with our destiny and tries to help us. Almost every day the donations that our brothers have collected overseas come to us. It will take many millions to build Carpathian Ukraine and that is why a brotherly help of foreign Ukrainians is very needful" ${ }^{\text {"542 }}$. Following a regular meeting in January 1939, the ODVU adopted a number of resolutions in favor of Carpathian Ukraine. "One of the most important decisions was to send clothes, shoes and other to Carpathian Ukraine," wrote University of Minnesota Professor O. Neprytsky-Gromovsky in a letter to UNO leader F. Revai. "The central administration of the ODVU has already sent 117 large packages to Carpathian Ukraine. Some of them weigh 350 kilograms. They contain shoes, clothes, leather and boots and other things. Each package is addressed to Prime Minister A. Voloshyn through the Red Cross. The packages contain approximately 400,000 pieces of clothing. This means that almost every Ukrainian in Carpathian Ukraine will have one pair of clothes" $" 543$. The ODVU also organized a company to collect medical equipment and medicines. It was planned to organize mass travel trips to Transcarpathia in the spring.

On January 5, 1939 Ukrainians sent "126 large packages of clothing and footwear to the Transcarpathian population. It is interesting to add that shipping from New York to Hamburg was supposed to cost the lowest tariff of 1680 dollars, but with the help of the AmericanCzechoslovakian Chamber the free shipping of these large packages

\footnotetext{
${ }^{541}$ Ibid. C. 96.

${ }^{542}$ Нова свобода. 1938. 13 листопада.

${ }^{543}$ Нова свобода. 1939. 4 лютого.
} 
was achieved" ${ }^{\text {"544 }}$. The government of Carpathian Ukraine had only to bring these things from Hamburg to Khust. "Nova Svoboda" newspaper informed its readers that "soon the second transport with things for our population will be sent from America to Carpathian Ukraine"545. Organizations of Ukrainians of the nationalist movement in the US treated the formation of Carpathian Ukraine as a stage in the revival of united Ukraine. According to them, the Ukrainian state in Transcarpathia "at the appropriate moment will unite with the Ukrainian Great State in Kyiv" "546. The disintegration of Czechoslovakia was not regarded by them as something tragic, since "in the place of today's Czechoslovakia three independent states should come: Czech Republic, Slovakia and Transcarpathian Ukraine. The thing is not at all fantastic - when there are Luxembourg, Andorra and Liechtenstein - and for the longer term, why should the Ukrainian Transcarpathian State not emerge - for a while, until it connects with Kyiv?, 547 .

For the sake of historical truth, it should be noted that among the Transcarpathian Diaspora in the United States there were many Russophiles and pro-Hungarian persons who were negative about A. Voloshyn and the politics pursued by his office. The Hungarian government relied on them in their claims to Transcarpathia. It is known that in October 1938 the Ministry of Foreign Affairs of Hungary handed over to the General Consul in Cleveland 10,000 dollars for revanchist propaganda among American Ruthenians ${ }^{548}$. We should also add that the government of Carpathian Ukraine did not do everything to ensure that Transcarpathians, who lived in the United States, received immediate true information about the political developments in the country. In this case V. Shandor's thoughts are worthy of note: "The world is interested in us far more than can be observed in the world political press or literature. Here,

\footnotetext{
544 Нова свобода. 1939. 23 лютого.

545 Ibid.

${ }^{546}$ Стерчо П. Карпатська Січ була школою активу похідних груп і УПА. Дмитро Климпуш - головний командант «Карпатської Січі»: Документи, спогади, cmammi, вірші / Упор. О. Д. Довганич, М. І. Кухта. Ужгород, 1997. С. 94.

${ }^{547}$ Ibid. C. 93.

548 Болдижар М. Закарпаття між двома світовими війнами. Ужгород, 1993. C. 131 .
} 
they have a noticeable general tendency to conceal the weight and importance of the Ukrainian problem, especially our neighbors and their allies, who are still demanding the territory of Ukraine. Unfortunately, the world is interested in the Ukrainian problem and knows about it often from alien, hostile sources more than from ourselves" $" 549$.

It should be noted that representatives of Russophilism in the United States also contributed to the Transcarpathian struggle for autonomous rights. During the Congress of the Subcarpathian Ruthenians, held in New York in February 1937, an ultimatum was adopted to the Czechoslovak government, demanding the Transcarpathian autonomy in 60 days. This ultimatum was to be handed to the Prime Minister of Czechoslovak Republic, M. Hodza, by one of the leaders of Russophilism and pro-Hungarian position in the region S. Fentsyk ${ }^{550}$. Significant work was done in Transcarpathia by a delegation headed by O. Herovskyi on the eve of the formation of A. Brodi's first autonomous government, which will be discussed below. The attitude of Russophiles to the region has changed dramatically since the appointment of A. Voloshyn as a Prime Minister. On January 15, 1939 the participants of the meeting in Ascona declared a protest "against the forced Ukrainianization of Carpathian Rus' by the current government on the orders of Berlin and with the help of Ukrainian emigrants"551. Participants of the "Lemko-Union" at their meeting, held on January 22, 1939 in Edson (Alta), condemning "the power of Pater Voloshyn", expressed their desire to annex Carpathian Rus' to the Soviet Russia ${ }^{552}$. The AllAmerican Carpatho-Rus' People's Congress on February 11-12, 1939 in New York condemned the policy of A. Voloshyn's government. However, it is necessary to agree with $\mathrm{M}$. Boldyzhar that "the congress still did not have an "all-American character", although it represented about 50,000 emigrants ${ }^{553}$. The open pro-Hungarian

\footnotetext{
549 Шандор В. Спомини. Т. 1. Карпатська Україна. 1938-1939. Ужгород: МПП «Гражда»; Карпатський Союз, 1996. С. 239.

${ }^{550}$ Болдижар М. Закарпаття між двома світовими війнами. Ужгород, 1993. С. 71.

551 Ibid. C. 132.

552 Ibid. C. 133.

553 Ibid. C. 134.
} 
orientation of the leader of the "Carpatho-Rus' Union" in the USA caused dissatisfaction even among its members, in particular those who adhered to the pro-Czech orientation. On March 7, 1939 there was a forum of this organization in Pittsburgh, which condemned the pro-Hungarian course of the leadership. "Moreover," wrote V. Lemak, "O. Herovskyi was asked to leave the meeting room, and I. Pop followed him"554. About the position occupied by the "Carpatho-Rus' Union" in the time of O. Herovskyi it was written in the work by P.R. Magocsi ${ }^{555}$.

On March 20, 1939 a new meeting was held in New York to condemn "Hitler's agents among the Ukrainian people in America, who, having covered themselves with nationalism, make Ukrainians ashamed before the American democratic people with statements and declarations that with the help of Hitler the Ukrainian people are moving to the creation of their state" 556 . M. Boldyzhar, who cites this document, is certainly aware that A. Voloshyn's government had no choice in orientation. As for the resolution he cited, it was adopted after the tragedy of Carpathian Ukraine, that is, when confusion was inherent not only to US Ukrainians but also to Galicians. We believe that in adopting this paragraph of the resolution the participants of the meeting tried, above all, to condemn fascism in general and its expansionist policies.

Ukrainian emigration in Canada has also declared its readiness to help Carpathian Ukraine. Particular activity was shown by the members of the UNO organization. The "Committee of Help to Carpathian Ukraine" (hereinafter referred to as the DCCU) was established on its initiative with a center in Saskatoon. By midJanuary 1939, the DCCU had raised 325,122 dollars $^{557}$. Assistance from the "Brotherhood of Ukrainian Catholics" in Canada was also received $-7,500$ dollars, and with private parcels reaching up to

\footnotetext{
554 Лемак В. «Відкидаємо спосіб обманювання всього світу...». Американські русини і проблема вирішення автономії Підкарпатської Русі 20-30-х років. Карпатський край. 1995. № 9-12. С. 65.

555 Магочій П.Р. Формування національної самосвідомості: Підкарпатська Русь (1848-1948). Ужгород, 1994. С. 146.

${ }^{556}$ Болдижар М. Закарпаття між двома світовими війнами. Ужгород, 1993. С. 135.

${ }^{557}$ Нова свобода. 1939. 11 січня.
} 
100,000 dollars. In general, Ukrainian emigration in Canada planned to transfer 150,000 dollars to Carpathian Ukraine ${ }^{558}$. "Ukrainian Rifle Community" in Saskatoon has sent 5200 dollars to Carpathian Ukraine $^{559}$. In March 1939 the DCCU in Canada appealed to Ukrainian farmers to help Transcarpathians with grain. In addition, the Ukrainians of Canada held an action "Easter for Carpathian Ukraine" ${ }^{, 560}$.

Avgustyn Voloshyn, as evidenced by his numerous letters of thanks, tried to personally respond to the receipt of funds from abroad. In a letter to the UNO leadership in Canada, the Prime Minister wrote: "Dear brothers and sisters! Your message from December 8, 1938, to which you have added a check for 1,550 dollars (One thousand five hundred and fifty dollars), has moved us to our heart. Thank you very much for your warm welcome and for such a generous gift. We ask you to convey our thanks to all the donors through your "New Way" authority. In particular, the name of V. Kossar, who was a former colleague in Uzhgorod, made a pleasant impression on me, with his signature below, that he is alive and that he worked one of the first in the Committee. I congratulate him warmly and his dear family. Our young state now faces the most important task: elections to the first Soim. Your sincere help will lead to our future victory. Glory to Ukraine! Your A. Voloshyn, Prime Minister" ${ }^{\prime \prime 561}$.

Here are some other letters of thanks by A. Voloshyn for providing financial assistance for the development of Carpathian Ukraine: "In Khust on day 3/II 1939. Mr. Ukrainian National Association in Saskatoon. For the received gift of 1300 dollars 37992.50 kč. Sent for the development of Carpathian Ukraine" "562 . "In Khust of Day 3/II 1939. Mr. Ukrainian National Association in Saskatoon. For the account received in the amount of 1250 dollars -

\footnotetext{
${ }^{558}$ Нова свобода. 1939. 19 січня.

559 Болдижар М. «Карпато-українська Свобода» писала...». Новини Закарпаття. 1995. 4 лютого.

${ }^{560}$ Нова свобода. 1939. 12 березня.

561 Басараб В., Вегеш М., Сергійчук В. Августин Волошин. Нові документи і матеріали про життя і смерть президента Карпатської України. Ужгород: Видавництво УжНУ «Говерла», 2006. С. 39-40.

${ }^{562}$ Ibid. C. 40.
} 
36678.75 kč. Sent for the development of Carpathian Ukraine",563 . "In Khust on February 23, 1939. Mr. Ukrainian National Association in Canada. For the received gift of 1100 dollars. Sent for the development of Carpathian Ukraine. I ask you to take our gratitude. With brotherly greetings: Dr. Avgustyn Voloshyn, Prime Minister. Glory to Ukraine!"564.

On March 3, 1939 A. Voloshyn expressed his gratitude to the UNO Regional Executive in Saskatoon for "assistance to Carpathian Ukraine": "We acknowledge receipt of your letter dated February 2, 1939 and the Montreal Bank check no. 04388 for the sum of 1100 dollars, and we ask you to accept our sincere thanks for this gift. We support with your gifts the "Sich" organization, which is developing well. The central power has not yet recalled its general, but we have not appointed him and he is not ruling here, even though the 7th week has passed since his appointment. The revision of citizenship will be conducted by our governments, it cannot harm our people. Warmly greet all ours. Glory to Ukraine! Your A. Voloshyn"565.

In early 1939 the holiday of Carpathian Ukraine took place at the largest radio station in São Paulo (Brazil). Its participants listened to the speech, after which "the concert of the artist M. Nemolovsky took place, whose program included Ukrainian songs". The "CarpathoUkrainian Freedom" newspaper, which was published in Prague, concluded with the words: "Although being distant from their native land, the faithful sons of Carpatho-Rus' and other Ukrainian lands are pleased with the success that Carpathian Ukraine has achieved"566. The Ukrainians of the Far East also did not stay away. Here the fundraising was held under the slogan "Donate for Carpathian Ukraine". "Nova Svoboda" quoted from the Ukrainian magazine "Far East" in Harbin as saying: "The board of the Ukrainian National Colony Manchukuo has decided to allocate 200 man. dollars to

\footnotetext{
563 Ibid.

564 Ibid.

565 Басараб В., Вегеш М., Сергійчук В. Августин Волошин. Нові документи і матеріали про життя і смерть президента Карпатської України. Ужгород: Видавництво УжНУ «Говерла», 2006. С. 41.

566 Болдижар М. «Карпато-українська Свобода» писала...». Новини Закарпаття. 1995. 4 лютого.
} 
Carpathian Ukraine"567. Altogether, thousands of Manchurian dollars have been raised in the Far East for Carpathian Ukraine.

The assistance of Ukrainians living in European countries was also noticeable. Prague remained one of the main centers of Ukrainian emigration. According to S. Vidnianskyi, in 19398 thousand emigrants arrived in Prague. The age of $82.6 \%$ of Ukrainian immigrants ranged between 15 and 34 years. Almost half of them had completed secondary, professional and higher education ${ }^{568}$. What about the Transcarpathian Ukrainians, as of November 1938, there were 700 people living in Prague ${ }^{569}$. They were united in the organizations "Prosvita", "Ukrainian Workers Academy", "Union of Subcarpathian Ukrainian Students" and "Union of Youth".

On November 1, 1938 "Nova Svoboda" published an appeal by Ukrainian emigrants in Prague, which emphasized that the "highest and most authoritative body of organized Ukrainian society" is the UCNR (Ukrainian Central People's Council) in Uzhgorod ${ }^{570}$. The authors of the appeal proposed to use the names "Ukrainian", "Carpathian Ukraine", to immediately create a "National Fund" and to transfer in his favor money from all lands where Ukrainians live, to pay more attention "to the process of awareness of the masses of the population. There should be no town, no village, no dwelling today, where there would be no Ukrainian literature, fliers, the press and the

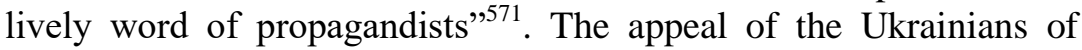
Prague made a huge resonance in the Czechoslovak Republic. "We must help the poorer, even if we are poor ourselves," P. Bohach wrote in the article "We can't leave the people of Subcarpathian Ukraine", "we cannot, therefore, leave that simple and hardworking people, who are characterized by their extraordinary ability to live and want to save the bare existence with the "rolled up sleeves" and save their families from starvation",572.

\footnotetext{
${ }^{567}$ Нова свобода. 1939. 11 березня.

568 Віднянський С.В. Українське питання в міжвоєнній Чехословаччині. Автореферат дисертації... доктора іст. наук. К., 1997. С. 19.

${ }^{569}$ Нова свобода. 1938. 1 листопада.

570 Ibid.

571 Ibid.

${ }^{572}$ Нова свобода. 1938. 21 листопада.
} 
At the beginning of 1939 the weekly "Carpatho-Ukrainian Freedom" began to be published in Prague, the materials of which were printed in Latin letters, and in each of its numbers there was a two-page insert with publications in the Ukrainian language. Along with the coverage of events that took place directly in Carpathian Ukraine, there were also their reviews, and the materials on the Ukrainian issue were presented in general ${ }^{573}$. There was a Radio Journal in Prague, which prepared radio programs for Transcarpathia and other countries. Following the appointment of A. Voloshyn as Prime Minister, a Ukrainian section was formed under the Radio Journal, which included M. Rusynko (Chairman), E. Shtefan (Deputy) and M. Ihnatyshyn-Lohush (Speaker) ${ }^{574}$. "The Ukrainian section," V. Shandor wrote, "broadcast seven times a day and ran a rich cultural program. Carpatho-Ukrainian radio programs were transmitted through radio stations: Bratislava-Banská BystricaPresov, and they were heard in Galicia. They informed about the events in Transcarpathia and denied attacks of the hostile, mainly the Hungarian and Polish, press and radio. Although the Ukrainian section was not numerous, it played an extremely important national role by only the fact that it was Ukrainian""575.

In more detail, the work of the Ukrainian section of the Radio Journal was described by its speaker M. Ihnatyshyn-Lohush: "Ukrainian radio programs from Prague had the following program: news - six times a day, ten minutes each; three times a week - on Mondays, Wednesdays and Fridays - 20 minutes each, and each Sunday -45 minutes. So for a few months we read the news at 10.15 in the evening, and at $7 \mathrm{am}$. I was in front of the microphone. Three times a week shortwave messages for North America were broadcast at 1:00 in the morning. I often spend the night in a radio house where I had a room for such occasions. In addition, every day we had a telephone connection with Khust to get the latest news from there, and when there was an important event - several times a day... For

\footnotetext{
573 Болдижар М. «Карпато-українська Свобода» писала...». Новини Закарпаття. 1995. 4 лютого.

574 Шандор В. Спомини. Т. 1. Карпатська Україна. 1938-1939. Ужгород: МПП «Гражда»; Карпатський Союз, 1996. С. 245.

${ }^{575}$ Ibid. C. 245-246.
} 
foreign press agencies, we translated in English, French and German languages important news, received from Khust... During the elections to the first Soim of Carpathian Ukraine on February 12, 1939, we had five minutes every day to inform about the election results. Throughout the day, we had a constant phone connection with Khust and we knew in what terrain we had a 98 percent lead in voting, leaving white flags there" ${ }^{\text {}}$.

Thanks to radio broadcasts from Prague, the world community received information about life in Carpathian Ukraine. The Ukrainian problem in radio broadcasting was constantly on the top. This state of affairs was of concern to the Soviet Union, which "through the mediation of newly built eight radio stations in the Soviet Ukraine, decided to fight on the air against the Czechoslovak radio station, which is in Ukrainian language and emphasizes the Ukrainian problem. Czechoslovakian Ambassador to Warsaw Dr. Yurij Slavik reported this to Prague" 577 .

Ukrainian emigration in Czechoslovakia held an action to help the Carpathian Sich, which "ended in very good success. All gathered resources helped to get 150 sets of uniforns (150 caps, cloaks, sweaters, ties, belts, boots and 300 pairs of linen). The rest of the money was sent in cash" ${ }^{\text {"578 }}$. Ukrainians of Prague, Brno and other cities have collected 100 thousand kč. "Nova Svoboda" published a letter from students of the Ukrainian gymnasium in Mordzhany (near Prague) to Ukrainian Central People's Council. It ended with the hope that "other Ukrainian children scattered around the world will be responding to your call". The successful holding of the assembly actions was facilitated by the activity of former UNR Directory members A. Makarenko and F. Shvets, who established close contacts with Representative Office of Carpathian Ukraine in Prague. "During my activities in Prague," V. Shandor recalled, "Prague Ukrainians and Ukrainians from all over the Czech Republic frequently visited our institution (Representative Office of Carpathian

\footnotetext{
576 Ігнатишин-Логуш М. «Слухайте Карпато-українську передачу...» звучало в ефірі. Срібна земля фест. 1996. 12-18 грудня.

577 Шандор В. Спомини. Т. 1. Карпатська Україна. 1938-1939. Ужгород: МПП «Гражда»; Карпатський Союз, 1996. С. 246.

${ }^{578}$ Нова свобода. 1939.8 березня.
} 
Ukraine in Prague - Aut.) and brought various projects for use in Carpathian Ukraine. They needed to be considered and evaluated. Some of the projects were very relevant and useful and we submitted them to Khust" ${ }^{\text {"579. }}$.

Among the proposals received by A. Voloshyn from Ukrainians of Czechoslovakia were such as joining Prešov region to Carpathian Ukraine, transfer of Ukrainian Free University from Prague to Khust, opening of Ukrainian educational institutions, etc. We should note that many of them were not within the competence of the government of the region. On November 15, 1938 A. Voloshyn received a delegation from the Prešov region, headed by teacher A. Kolenko. "...We look at Presov as a new center," A. Voloshyn said. "We will negotiate to get as much as possible for us. We will do everything to win a possibility for you to get where your nature, language and faith takes you. Do not be discouraged, we think and work for you. It is the matter of talks to have the secretariat of state at Bratislava by the time of border decision. We have no candidates yet. I want to agree with Presov representatives in this case" ${ }^{, 580}$. Delegates expressed the need to open a Ukrainian gymnasium in Medzilaborce.

In 1938 the Ukrainian Free University awarded A. Voloshyn the title of Honorary Doctor of Philosophy. "This is an extraordinary celebration of our honored father of the Ukrainian people for his more than forty years of work in the cultural field, which has now been crowned with great success!" - reported "Nova Svoboda" ${ }^{\text {"51 }}$. The issue of the transfer of Ukrainian Free University to the capital of Carpathian Ukraine has been repeatedly raised. "Ukrainian Free University," noted S. Vidniansky, "was founded primarily in view of the needs of inter-war emigration and its leadership considered the activity outside the native land as temporary, being ready at any favorable moment to move to Ukrainian land, where it is most

579 Шандор В. Спомини. Т. 1. Карпатська Україна. 1938-1939. Ужгород: МПП «Гражда»; Карпатський Союз, 1996. С. 352.

${ }^{580}$ Нова свобода. 1938. 17 листопада.

${ }^{581}$ Нова свобода. 1938. 1 листопада. 
needed" ${ }^{582}$. The transfer of Ukrainian Free University to Carpathian Ukraine became impossible due to the unfavorable international situation and the occupation of the land by the Horthy's troops.

Ukrainians in France were the first to respond to the call by Ukrainian Central People's Council and the government to adopt "the principle of collecting a half-percent tax from the payment" ${ }^{583}$. In March 1939 85,000 francs came to the "Fund of Development of Carpathian Ukraine" from France. The same was done by the Ukrainian workers in France, who "work hard in coal mines and do not earn much themselves..." ${ }^{\text {584 }}$. On the occasion of the 20th anniversary of the ZUNR (West Ukrainian People's Republic) proclamation, the Ukrainian society "Prosvita" in the French city of Chausee-le-Roi "organized an Academy on November 27, 1938, which collected 33 francs 75 centimes for our disabled people and 232 francs for the needs of Carpathian Ukraine" 585 .

The Ukrainians of Belgium were interested in the situation of the region. "Nova Svoboda" wrote: "Our subcarpathian workers work in the mines of Belgium, where they earn as much as 60-70 kč. daily. There are also people who have lived there for ten years, but everyone is interested in the events in their native Subcarpathia... Everyone said that the "state people" should be a greater lord on their land than they are now" "586. On November 13, 1938 a welcome telegram was sent to A. Voloshyn from "Flemings- friends of Ukraine, who send the most cordial gratulations on the occasion of the uprising of the Ukrainian Carpathian state. The truth won" ${ }^{\text {,587 }}$. For the Ukrainian from Italy M. Tovt «our biggest treasure is the free Carpathian Ukraine! Carpathian Ukraine is like one chain, and the parts of this chain are us, the Ukrainians. The chain, in order not to break, must consist of all the strong parts. To be strong, Carpathian Ukraine must throw out all the

\footnotetext{
582 Віднянський С.В. Культурно-освітня і наукова діяльність української еміграції в Чехо-Словаччині: Український вільний університет (1921-1945рр.). К., 1994. С. 140-142.

583 Стерчо П. Карпато-Українська держава: 3 історії визвольної боротьби карпатських українців у 1919-1939 роках. Торонто, 1965. С. 108.

${ }^{584}$ Нова свобода. 1938.14 грудня.

${ }^{585}$ Нова свобода. 1938. 6 грудня.

${ }^{586}$ Нова свобода. 1938. 9 вересня.

${ }^{587}$ Нова свобода. 1938. 17 листопада.
} 
bad "parts" and replace them with healthy, strong and conscious citizens, who would not be subject to any hostile propaganda in the disinterest of our Ukrainian national state. We must unite as much as the parts of the chain are united, then our Carpathian Ukraine will stand on strong feet" ${ }^{\text {"588. }}$. In February 1939 Swedish journalists visited Carpathian Ukraine, they wanted to make sure that there was "complete order and silence" on the territory of the region" $" 589$. Shortly after their visit, the Swedish charitable association "Radda Bernek" sent 6 parcels weighing $150 \mathrm{~kg}$ to $\mathrm{V}$. Shandor, the commissioner of guardianship of fugitives in Prague ${ }^{590}$.

According to the Romanian census conducted in 1931, 600,000 Ukrainians lived in Bessarabia and 300,000 in Bukovina ${ }^{591}$. The government of Carpathian Ukraine has been constantly monitoring the situation in Romania. On the pages of Transcarpathian periodicals we can find information that "the Romanian authorities... these days (August 8, 1938 - Aut.) began to work out the Romanian statute of nationalities. The statute should standardize the lives of the Hungarian, German, Ukrainian and Russian national minorities. The main points of the statute are: 1) prohibition of ruining of nation's features; 2) free use of the mother tongue in governments, churches, self-governing institutions; 3) the nationality of the child is determined by relatives when writing to the matrix; 4) freedom of cultural organizations of national minorities"592.

"Ukrainians in Romania are pleased with our success" - under this title "Nova Svoboda" published a letter from the Romanian city of Bystrica. "All Ukrainians," it said, "wherever they lived, have been following the events in Carpathian Ukraine for a long time. Ukrainians in Romania are pleased that at least our brothers in Carpathian Ukraine have gained their full freedom and can live free lives on their land and can make the order which most meets the

\footnotetext{
${ }^{588}$ Нова свобода. 1938. 16 грудня.

${ }^{589}$ Нова свобода. 1939. 2 березня.

${ }^{590}$ Нова свобода. 1939. 2 березня.

${ }^{591}$ Нова свобода. 1938. 23 жовтня.

592 Ibid.
} 
needs of the Ukrainian people"593. An important factor in the loyalty of the Romanian government to the region was the activity of the Ukrainian national minority. On October 16, 1938 Bucharest radio reported that "Ukrainians in Romania are developing lively activities against the accession of Subcarpathia to Hungary. This action proposes, among other things, that the accession of Subcarpathia to Hungary could reinforce the Hungarian revisionist tendencies towards Transilvania, which would be covered on three sides by the Hungarian border. Ukrainian action seeks to evoke intention in Romania that would be contrary to the Hungarian plans" message evidences that the main reason for Romania's loyal attitude to Carpathian Ukraine is the threat posed by Hungary's proximity to the Romanian border.

In Vienna there was a "Committee of Support of Carpathian Ukraine" headed by O. Levytska and O. Hrytsai. After the occupation of Transcarpathia, the DCCU was headed by the head of the regional OUN Yu. Khymynets, and his active assistants were M. Khymynets, M. Pankewychivna and R. Haras. "The first and most important thing for us," recalled M. Khymynets, "was to accept transport and register refugees. The healthy persons had to be taken to "Schober Platz" in Vienna, where they waited for their work or for the travel to Prague or Bratislava. Ill persons had to be treated separately. This problem became very urgent when in May 1939 prisoners from the Voruloposci concentration camp from Hungary began arriving. Most of them were so crippled and beaten that they needed hospital treatment. I took care of the sick and the children. We were lucky to place the sick and the cripples from the Hungarian concentration camp in local hospitals and sanatoriums" ${ }^{, 595}$. From the outset, the DCCU in Vienna worked in conjunction with the Foreign PUN and the German Army Main Command. According to the head of the

\footnotetext{
593 Нова свобода. 1938. 27 грудня; Lidove Listy. 1938. 11 decembrie; Narodni Politika. 1939. 7 ianuarie; Venkov. 1939. 19 ianuarie.

${ }^{594}$ Нова свобода. 1938. 17 грудня; Curentul. 1938, 24 octombrie; Frontul. 1938, 28 noembrie.

595 Химинець М. Жінки Закарпаття - дома й на чужині. Краянка. 1994. С.46-48; Химинець М. Організоване жіноцтво Карпатської України (1919-1939). Украӥнські Карпати: етнос, історія, культура. Матеріали міжнародної наукової конференції. Ужгород, 1993. С.500-514.
} 
DCCU Yu. Khymynets, "at that time it was almost the only way to send our people out of Hungarian captivity"596. Thanks to the active work of the DCCU members, about 900 people were transported from Vienna to the Czech Republic and Slovakia, and 52 children were transferred to the Ukrainian gymnasium in Mordzhany.

In Yugoslavia there lived many Ukrainians, "who, even under Maria Theresa, left the inhospitable Presov peak and settled in the fertile fields of Bačka, in Krstur",597. On July 30, 1938 "Nova Svoboda" interviewed the editor-in-chief of the "Rus' News" and "Native Word" in Krstur, M. Firak, who concluded that the Ukrainians in Yugoslavia had all the conditions for their national and cultural development. Thus, there were 1,200 copies of the newspaper "Rus' News" for 40,000 Ruthenian-Ukrainians in Backa, while for the Galicians and Bukovinians living in Bosnia, 800 copies of the "Native Word" were published. There was a cultural and educational society "Prosvita" in Krstur, there was a printing house where these magazines were published. According to M. Firak's deep conviction, "all inhabitants of Backa are nationally conscious, although they speak a Saris dialect! They are further away from our Saris people!"598. The editorial office of "Nova Svoboda" was outraged by the publication in the Slovak magazine "Slovenski Glas", which stated that the Ukrainians of Yugoslavia were "put there at risk of losing native character"599. "Although the Slovak chauvinists a bit late remembered our Backa brothers," "Nova Svoboda" wrote, "we still need to be prepared for an attempt of uninvited Slovak encroachment on our life in Backa"600.

The Ukrainians of Yugoslavia were pleased to hear the news that Transcarpathia had been granted autonomous rights and an attempt by the government of Carpathian Ukraine to lead an independent state life. In the article "Backa Ukrainians to Carpathian Ukraine", "Nova Svoboda" reported: "The independence of their ancient homeland caused great joy among Ukrainians in Backa. For this reason they

\footnotetext{
596 Химинець Ю. Закарпаття - земля української держави. Ужгород, 1992. С. 283.

${ }^{597}$ Нова свобода. 1938. 20 листопада.

${ }^{598}$ Нова свобода. 1938. 30 листопада.

${ }^{599}$ Нова свобода. 1939. 9 вересня.

${ }^{600}$ Ibid.
} 
want to manifest their joy not only in words but also in deeds, and that is why the Backa edition "Rus' News", published in Ruski Krstur, calls to unite for the benefit of the brothers from Carpathian Ukraine"601. "Interest in the affairs and needs of Carpathian Ukraine in Yugoslavia began to grow day by day," wrote E. Matsiakh, "together with the US and Canadian dollars, although not in such sizes, but very generously, the Yugoslav dinars also came. Unfortunately, it was not yet finished the collecting when there came the thunderous news that Hungarian riders hit the Silver Earth Carpathian Ukrainian state" 602 .

The Ukrainians of Yugoslavia ached for the news of A. Brodi's betrayal, who was "arrested and there was an inspection at Brodi's premises in Vienna audited by the Viennese police. The audit revealed that he was an agent of the Hungarian government"603. Several issues of the Croatian magazine "Hrvatska Strazha" included A. Voloshyn's appeal to the Ukrainian people. Yugoslav periodicals welcomed government's desire to establish Ukrainian university in Carpathian Ukraine ${ }^{604}$, and Zagreb Radio noted on March 1, 1939: "Ukrainian case is gaining more and more importance and interest in the world. Carpathian Ukraine is a particular point of interest" ${ }^{\$ 605}$.

From the memories of V. Shandor it is evident that he, on behalf of the Government of Carpathian Ukraine, informed the Yugoslav Government of the act of declaration of independence ${ }^{606}$. However, at the time it was a more symbolic act than real politics. The fate of Carpathian Ukraine has been resolved. On March 25, 1939 "Ridne Slovo" made an inscription on the entire first page: "The heroic struggle for freedom of Carpathian Ukraine with the Hungarian invaders". In the article we find such subheadings as "Bloody struggle with the Magyars", "Slovakia an independent state", "Czech state does not exist", "First victims", "People's power and UNO",

\footnotetext{
${ }^{601}$ Нова свобода. 1938. 6 грудня.

602 Організація Українських Націоналістів (1929-1954). Вінніпег, 1955. С. 396-397.

${ }^{603}$ Нова свобода. 1939. 1 січня.

${ }^{604}$ Нова свобода. 1939. 5 січня.

${ }^{605}$ Нова свобода. 1939. 3 березня.

${ }^{606}$ Шандор В. Спомини. Т. 1. Карпатська Україна. 1938-1939. Ужгород: МПП «Гражда»; Карпатський Союз, 1996. С. 337.
} 
"New power", "Soim declares independence" and "Heroic Fighting with the Magyars". "Ukrainians in Carpathian Ukraine," "Ridne Slovo" reported, "fought for Truth and Justice! The enemy drew a sword at us. He will die for this, and we will rise again!" ${ }^{607}$. In "Ridne Slovo" there were articles entitled "Blood written history of Carpathian Ukraine", "Students in the front ranks", "Conscious peasants in the struggle", "We will not return home alive", "In Bilky all gymnasium students have fallen down dead", "Fights of the Carpathian Sich Riflemen in the middle of Carpathian Ukraine", "The Future of Carpathian Ukraine", "The Shameful Role of General Prchala" ${ }^{\prime 608}$. There were large articles about Carpathian Ukraine in "Rus' Calendar" and various periodicals and books of Ukrainians of Yugoslavia $^{609}$. Evidence of the commitment of the Ukrainians of Yugoslavia to Carpathian Ukraine was the friendly attitude of representatives of the government of A. Voloshyn and ordinary refugees who were forced to leave the territory of the region in the tragic days of 1939. Galician magazine "Women's Will" posted a short message: "Fr. Dr. A. Voloshyn celebrated Easter in Yugoslavia" ${ }^{\prime 10}$. In this country he visited the cities of Belgrade, Zagreb and Crikvenica ${ }^{611}$.

At the request of D. Njaradi, residents of the Ruski Krstur gave a shelter to 200 emigrants from Carpathian Ukraine ${ }^{612}$. As for D. Njaradi, in 1939 he was appointed papal administrator in Carpathian Ukraine and "was characterized by his patriotism, which differed from the distinctive pro-Hungarian position of the clergy". Following D. Njaradi's request, Ukrainian patriots in Yugoslavia did

\footnotetext{
607 Мизь Р. Відгуки на проголошення Карпатської України та іiі трагедії в українській пресі Югославії. Карпатська Украӥна $i$ Августин Волошин. Матеріали міжнародної наукової конференції. Ужгород, 1995. С. 125. ${ }^{608}$ Ibid. C. $125-126$.

609 Паплацко В. Формованє и трагедия Карпатскей України по писаню Руских новинох и Руского календара за 1940 рок. Карпатська Украӥна $і$ Августин Волошин. Матеріали міжнародної наукової конференції. Ужгород, 1995. С. 276-283. 610 Жіноча воля. 1939. Ч. 5.

611 Центральный архив Министерства государственной безопасности РФ. Н-17681, л. 11-12.

612 Олеяр Я. Духовни и церковни вязи Руского Керестура зоз Закарпатську Україну, Пряшовщину и Галичину. Культура Украӥнських Kapnam: традищії $i$ сучасність. Матеріали міжнародної наукової конферениії. С. 427.
} 
their best to make the refugees from Carpathian Ukraine feel at home. "My task," M. Kovach recalled, "was to organize food and accommodation in the houses, and to find a way to support our dear guests further. And we were not wrong. The whole village (Ruski Krstur - Aut.) accepted the refugees as their truly relatives. I was helped by peasants, students, members of society, everyone. There was organized the collecting of products, food, etc... And not only in R. Krstur, but also in the villages and towns where our people lived..." ${ }^{\prime 13}$. According to M. Kovach's estimates, 189 people, mostly intellectuals, came to Ruski Krstur.

The Transcarpathian intelligentsia in Ruski Krstur was worthily represented by the famous theatrical figure of the region Yu. A. Sherehii, who came at the invitation of M. Firak ${ }^{614}$. Ya. Oleyar mentioned that Yu. Sherehii wrote six plays ${ }^{615}$. For the period from April 23 to June 18, 1939 the theater "New Scene" staged performances "Zaporizhia Treasure" and "Fair in Sorochyntsi", which "were played for Ukrainian Transcarpathian emigration"616. On August 13, 1939 in Miklosevce, the actors of the theater staged the folk drama of Sukhodolsky "The Cloud", and on October 29, 1939 - the drama of Yu. Hrom "On the threshold of the baptism of Rus" in Krstur. In November 1939, Y. Sherehii was granted a residence permit in the Croatian city of Shidi. The "Yugoslav period" in the life and work of Yu. Sherehii was quite fruitful. As the director later recalled, he "wrote... another drama from the life of the inhabitants of Backa "Unmarried" and "Pan", the plays about peasant life in 4 parts... Both were published in "Calendars" in Ruski Krstur and

613 Ковач М. Березнева ніч: [Біженці з Карпатської України в Руському Керестурі]. Карпатська Січ: Матеріали науково-практичної конференції, присвяченої 56-ій річниці Карпатської Січі. Ужгород: МПП «Гражда», 1996. C. $184-186$.

614 Шерегій Ю. Нарис історії українських театрів Закарпатської України до 1945 року. Нью-Йорк - Париж - Сідней - Торонто - Пряшів - Львів, 1993. С. 325.

615 Олеяр Я. Просвитни, школски и културни вязи у прошлости Руского Керестура (Бачка) зоз Закарпатйом, Пряшовщину и Галичину-Горніцу. Украӥнські Карпати: етнос, історія, культура. Матеріали міжнародної наукової конферениії. - С. 363.

616 Шерегій Ю. Нарис історії українських театрів Закарпатської України до 1945 року. Нью-Йорк - Париж - Сідней - Торонто - Пряшів - Львів, 1993. C. 324 . 
Dervent (1940 and 1941)"617. D. Latiak, evaluating the presence of the "New Stage" in Yugoslavia, noted that "although they did not live for a long time in Ruski Krstur, they left a deep trace in the revival of theatrical life among the Yugoslav Ruthenians"618. Yu. Sherehii's plays "are still mentioned today by older residents of Ruski Krstur"619. The famous director also taught Ukrainian folk dances in the Rus' localities of Backa, Srem and Slavon.

Vienna arbitration has not only struck an irreparable blow to all the leading sectors of the economy, it has, in fact, left the autonomous Ukrainian state without highly qualified specialists. Carpathian Ukraine lost $78146(45.11 \%)$ of farmers and forestry workers, $31350(18.10 \%)$ of industry workers and artisans, $17658(10.11 \%)$ of trade workers and workers of financial authorities, $7177(4.14 \%)$ of transport workers, $19754(11.40 \%)$ of civil service workers, of free and soldiers, 19148 $(11.06 \%)$ of others ${ }^{620}$. There were almost no intellectuals left in the country.

This state of affairs has not withstood any criticism. The government of Carpathian Ukraine has made considerable efforts to attract highly qualified specialists to the national economy. The Ukrainian Emigrant Bureau in Carpathian Ukraine, which emerged on December 10, 1938, played a significant role in this case. During the first period the Bureau did a considerable amount of work to find the specialists, who were recruited to work in various sectors of the national economy. The government of Carpathian Ukraine has set high salaries for them. For example, K. Osaulenko from Prague, received a salary of 1500 kč, engineers H. Rudenko, A. Pasichny, V. Frantyk - at 1 200-1 500 kč, professor V. Melnyk - $1200 \mathrm{kč}^{621}$. After a while, the Bureau "was mainly concerned with giving Carpatho-Ukrainian citizenship to some of

\footnotetext{
${ }^{617}$ Ibid.

618 Латяк Д. Улога українських діячох у националим освидоменю руснацох. Дзвони. Християнски календар за 1995 рок. На чесц 250-рочніци приселєня. Нови Сад, 1994. С.181.

619 Олеяр Я. Просвитни, школски и културни вязи у прошлости Руского Керестура (Бачка) зоз Закарпатйом, Пряшовщину и Галичину-Горніцу. Украӥнські Карпати: етнос, історія, культура. Матеріали міжнародної наукової конференції. - С.363.

${ }^{620}$ Болдижар М. Закарпаття між двома світовими війнами. Ужгород, 1993. С. 101.

${ }^{621}$ ДАЗО. Ф. 3. Оп. 1. Спр. 43. Арк. 32-34.
} 
the nationalist elements. The presence of such citizenship made it possible to obtain Czechoslovak citizenship and thus to carry out their activities freely" ${ }^{622}$. M. Boldyzhar believes that "the involved personnel did not have a special influence on the economic development of the region" 623 , which is impossible to agree with.

Hundreds of letters were received by A. Voloshyn, whose authors requested the prime minister's permission for citizenship, expressed their desire to work for the benefit of the development of Carpathian Ukraine. The letters were written by experts from different fields of knowledge, whose fate thrown them beyond Ukraine. The vast majority of the letters came from former UGA soldiers, members of the OUN, who at one time emigrated abroad, trying to escape Polish and Bolshevik terror. Former Imperial Army colonel F. Yuriev, who resided in Germany, requested to be hired in the field of jurisprudence. He had higher military and juridical education, worked for a long time as a judge, investigator, prosecutor ${ }^{624}$. In a letter to A. Voloshyn, S. Fedorov listed all the positions he held during his life: "Doctor of Law, Engineer-Economist, Military and Naval Aeronaut, Colonel of the Kuban Army, of Ukrainian Army and of Engineering Troops of the former Russian Fleet and Naval Office" ${ }^{\text {"625. }}$. However, he did not receive permission to come to Carpathian Ukraine.

On December 10, 1938 a letter from M.S. Pavlenko, who was at that time residing in Iran, was sent to the Czech Foreign Ministry. He offered his services as a graduate of the Kharkiv Agricultural Institute and a land reclamation specialist. "When the country is in need for specialists, I will be glad to come to your permission" 626 , he wrote. A. Voloshyn replied: "We have many unemployed people, evacuation, may be it would be better later?"627. B. Teslenko from Kharkiv, who has lived in Iran since 1937, offered his services to the autonomous country. He was a famous scientist. In 1932 B. Teslenko defended his dissertation and received the degree of associate professor at the Department of Iranian Philology. At the same time, he was a corresponding member of the All-Ukrainian

\footnotetext{
${ }^{622}$ Болдижар М. Закарпаття між двома світовими війнами. Ужгород, 1993. С. 88.

${ }^{623}$ Ibid. C. 89.

624 ДАЗО. Ф. 3. Оп. 1. Спр. 56. Арк. 5.

625 ДАЗО. Ф. 3. Оп. 1. Спр. 54. Арк. 2.

626 ДАЗО. Ф. 3. Оп. 1. Спр. 56. Арк. 1.

627 ДАЗО. Ф. 3. Оп. 1. Спр. 56. Арк. 2.
} 
Scientific Association of Orientalists and took part in two research expeditions to the countries of Central Asia. Intensive scientific activity did not prevent B. Teslenko to be actively engaged in political activity in the ranks of the illegal OUN ${ }^{628}$.

Well-known architects who lived in different countries of the world offered their knowledge and experience. For example, Prague-based engineer and architect S. Dzydz published an article in "Nova Svoboda" "Where the capital of Carpathian Ukraine should be?", in which he proved the necessity that "capital... should be built the way that it would be worthy of that name and to be the pride of the Ukrainian people" ${ }^{\text {"29 }}$. The author of the article wrote about the extreme importance of the geographical location of Khust, because "the capital is located on the main routes that will connect it with the world internal and external",630. The author of the first book on Ukrainian architecture, M. Shumnytsky, who has lived in France since 1921, wanted to help Carpathian Ukraine. In a letter to A. Voloshyn, he wrote that he would do his best to "make Khust a big modern city" ${ }^{\prime \prime 31}$.

P. Manchenko, a graduate of the Ukrainian Economic Academy in Podebrady, send a request "for appointment to a teaching service in Carpathian Ukraine" 632 . A desire to work for the benefit of the region was expressed by of V. Akindinov from Podillya ${ }^{633}, \mathrm{H}$. Sholudko from Harbin $^{634}$, A. Bibikov from Kyiv ${ }^{635}$. Yu. Horodianyn-Lisovsky actively participated in the fight against the Bolsheviks, and in 1924-1931 he "stayed in the Bolshevik prison" "636. It is unknown what his profession was. O. Krasytsky, who lived in Vienna, wrote to A. Voloshyn: "Following the Viennese happy reports on the events in Transcarpathia, I have a hope again to serve our unfortunate people once again and with my modest powers to take - even microscopically small - part in the

628 ДАЗО. Ф. 3. Оп. 1. Спр. 36. Арк. 5.

${ }^{629}$ Нова свобода. 1939. 15 лютого.

${ }^{630}$ Ibid.

631 ДАЗО. Ф. 3. Оп. 3. Спр. 173. Арк. 53.

632 ДАЗО. Ф. 17. Оп. 2. Спр. 369. Арк. 2.

633 ДАЗО. Ф. 17. Оп. 2. Спр. 344. Арк. 1.

634 ДАЗО. Ф. 17. Оп. 2. Спр. 372. Арк. 1.

635 ДАЗО. Ф. 17. Оп. 2. Спр. 346. Арк. 1.

636 ДАЗО. Ф. 17. Оп. 2. Спр. 372. Арк. 1. 
resurrection of their rights" ${ }^{\text {, } 37}$. There are many examples of this. They testified that Ukrainians, who had been thrown by their fate into different corners of the world, sincerely wanted to help Carpathian Ukraine at a difficult time. However, in the vast majority of cases, A. Voloshyn responded with a refusal. At Fershman's request, he wrote: "We cannot accept your request favorably"638. Engineer M. Hryhoriev was also denied due to the fact that "there are still no vacancies in the civil service"639. Therefore, despite the lack of highly qualified personnel, the government of Carpathian Ukraine made a careful selection of a large number of people wishing to serve the young autonomous state.

Thus, the government of Carpathian Ukraine established relations with many organizations and societies of the Ukrainian diaspora, which organized fundraising, food and provided other material assistance to the Transcarpathian population. Particularly noticeable was the financial assistance that came regularly from the US and Canada, in particular, from the ODVU, the DCCU, the UNO and so on. At the same time, it should be noted that Ukrainian emigration over the ocean was quite diverse. As for the Transcarpathians, they usually represented two camps - Russophiles and Narodovtsi (Ukrainian). While the former supported the formation of the autonomous government of A. Brodi, the latter were pleased to hear the news of his overthrow and the appointment of Prime Minister A. Voloshyn, the brightest representative of the Ukrainian direction in the country. This explains the diversity of approaches to assessing the very formation of Carpathian Ukraine and the policy pursued by its government. Ukrainian organizations in Europe and Asia did not remain aloof. The various "Support Committees" operating in Prague and Vienna have done considerable work. Support for the government of Carpathian Ukraine was reflected in the hundreds of letters that were constantly sent to A. Voloshyn. Their authors expressed a desire to work for the benefit of the young autonomous country, to be involved in its development.

637 ДАЗО. Ф. 3. Оп. 2. Спр. 52. Арк. 4.

638 ДАЗО. Ф. 3. Оп. 3. Спр. 87. Арк. 17.

639 Ibid. 